Sustainability, Agri, Food and Environmental Research, (ISSN: 0719-3726), 10(X), 2022:

http://dx.doi.org/

\title{
A feasibility study to produce biodiesel from date seed oil by using trans-esterification process.
}

\section{Un estudio de viabilidad para producir biodiésel a partir de aceite de semilla de dátil mediante un proceso de transesterificación}

\author{
Athraa Aziz Saif Aziz AL-Hasni, and S.V. Satyanarayana* \\ Department of Civil and Environmental Engineering, National University of Science \\ and Technology. Muscat, Oman. \\ *Corresponding author's email: satyanarayana@nu.edu.om
}

\section{ABSTRACT}

There is a need to produce renewable energy resources to reduce the gap between supply and demand. The renewable energy can be generated from various kinds of resources likevegetable oils and animal fats. Biodiesel is one of alternative energy resources that can bean appealing option to solve many of global and environmental issues and crises. Production of biodiesel from several types of vegetable oils has become a promising option. The aim of this technical project is to produce biodiesel from date seed oil. The date seed oil is extracted from the date seeds. The date seed is mixed with methanol in 1:3 ratio in presence of catalyst. The mixture was kept in a hot air oven at 55-60 degreescentigrade for six hours. The Trans esterification process produced a glycerol and methyl ester which is the biodiesel. The glycerol settled down due to its high-density and the upper layer was biodiesel (methyl ester) due to less density. The mixture was separated using a separating funnel. The biodiesel was purified by recovering methanol by using rotary evaporator. The biodiesel produced from date seed oil is analyzed for the viscosity, density, the calorific value was also obtained, and the Flash and Fire point was performed, determine the functional elements of biodiesel using Gas Chromatography. It was observed by gas chromatography analysis that the produced biodiesel contains nearly $70 \%$ of methyl ester which is a main component of biodiesel. The density of produced biodiesel was $0.895 \mathrm{~g} / \mathrm{cm} 3$. The standard biodiesel density is $0.85 \mathrm{~g} / \mathrm{cm} 3$. The results werecompared with standard biodiesel values. Also, the produced biodiesel has been compared with the quality of standard biodiesel. The project yielded better results.

Keywords: biodiesel, date seed oil, flash point, Trans- esterification. 
Sustainability, Agri, Food and Environmental Research, (ISSN: 0719-3726), 10(X), 2022: http://dx.doi.org/

\section{RESUMEN}

Es necesario producir recursos energéticos renovables para reducir la brecha entre la oferta y la demanda. La energía renovable se puede generar a partir de varios tipos de recursos como aceites vegetales y grasas animales. El biodiesel es uno de los recursos energéticos alternativos que puede ser una opción atractiva para resolver muchos de los problemas y crisis ambientales y globales. La producción de biodiésel a partir de varios tipos de aceites vegetales se ha convertido en una opción prometedora. El objetivo de este proyecto técnico es producir biodiesel a partir de aceite de semilla de dátil. El aceite de semilla de dátil se extrae de las semillas de dátil. La semilla de dátil se mezcla con metanol en una proporción de 1: 3 en presencia de catalizador. La mezcla se mantuvo en un horno de aire caliente a 5560 grados centígrados durante seis horas. El proceso de transesterificación produjo un glicerol y un éster metílico que es el biodiésel. El glicerol se asienta debido a su alta densidad y la capa superior era biodiesel (éster metílico) debido a su menor densidad. La mezcla se separó usando un embudo de decantación. El biodiesel se purificó recuperando metanol usando un evaporador rotatorio. En el biodiesel producido a partir del aceite de semilla de dátil se analiza la viscosidad, densidad, también se obtuvo el poder calorífico y se realizó el Punto de

Inflamación y Fuego, determinar los elementos funcionales del biodiesel mediante Cromatografía de Gases. Mediante el análisis de cromatografía de gases se observó que el biodiésel producido contiene casi un $70 \%$ de éster metílico, que es un componente principal del biodiésel. La densidad del biodiésel producido fue de 0,895 g / cm3. La densidad estándar del biodiésel es de $0,85 \mathrm{~g} / \mathrm{cm} 3$. Los resultados se compararon con los valores estándar de biodiésel. Además, el biodiésel producido se ha comparado con la calidad del biodiésel estándar. El proyecto arrojó mejores resultados.

Palabras clave: biodiesel, aceite de semilla de dátil, punto de inflamación, transesterificación.

\section{INTRODUCTION}

The petroleum diesel is an essential and traditional non-renewable source which is an important source despite the disadvantages and environment considerations. The crude oil-based petroleum products are the major source of non-alternative sources of energy in 
the world. The cost of petroleum products is increasing steadily. The crude oil reserves are limited in the earth's crust. The fossil fuels one of earth's limited sources and it may be lost within 50 years. Furthermore, the fossil fuels such as; diesel and petrol through combustion process releases carbon mono oxide, carbon dioxide, oxides of nitrogen, Sulfur dioxide and other suspended particulate matter which are harmful to the environment. The combustions of fossil fuel are producing greenhouse gases as a result global warming is increasing.

\section{MATERIALS AND METHODS}

The best quality date seeds which contain polyunsaturated fatty acids and protein are collected. Date seed oil extracted with the help of ORIGO Integrated Projects LLC. The date seed oil and methanol were mixed in 1: 3 ratio and subjected to Trans-esterification process (Fig. 1).

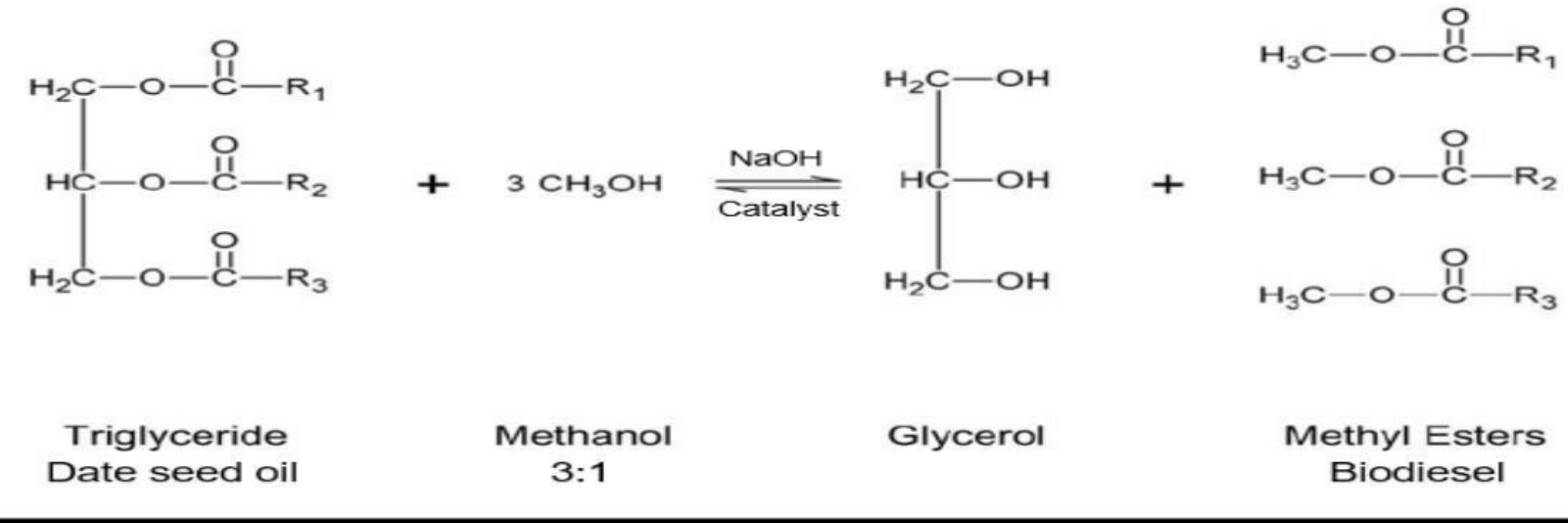

Fig. 1. The transesterification reaction.

Date seed oil $100 \mathrm{ml}$ transferred into a round bottom Erlenmeyer flask. $300 \mathrm{ml}$ of methanol was added to the date seed oil and 4 grams of sodium hydroxide was added to the mixture. The mixture was kept in hot air oven at 55-60 degrees centigrade for six hours. The triglycerides in the date seed converted into methyl ester (biodiesel) and glycerol. After complete transesterification process two different layers are formed in the Erlenmeyer flask. The top layer is biodiesel due to low density and the high-density glycerol settles down. The biodiesel is separated with the help of separating funnel. 


\section{RESULTS AND DISCUSSION \\ DENSITY OF BIODIESEL}

The density of biodiesel is calculated with the below formula.

$$
\rho=\frac{m 2-m 1}{v}
$$

Where:

$=$ Density pf biodiesel in $\mathrm{g} / \mathrm{m}^{3}$

$\mathbf{m 1}=$ Mass of empty pycnometer in gram.

m2 Mass of the pycnometer with biodiesel in gram

$=$ Volume of pycnometer in $\mathrm{ml}$ or $\mathrm{cm}^{3}$

The density values of the biodiesel are shown in Table 1.

Table 1: The density values of biodiesel

\begin{tabular}{lcccc}
\hline $\begin{array}{l}\text { Sample } \\
\text { no }\end{array}$ & $\begin{array}{c}\text { Empty Pycnometer } \\
(\mathrm{m} 1)\end{array}$ & $\begin{array}{c}\text { Pycnometer }+ \\
\text { biodiesel }(\mathrm{m} 2)\end{array}$ & $\begin{array}{c}\text { Volume of } \\
\text { Pycnometer }(\mathrm{v})\end{array}$ & $\begin{array}{c}\text { Density } \\
\mathrm{g} / \mathrm{m}^{3}\end{array}$ \\
\hline 1 & $26.007 \mathrm{~g}$ & $76.359 \mathrm{~g}$ & $50 \mathrm{ml}$ & 1.00564 \\
2 & $26.624 \mathrm{~g}$ & $75.914 \mathrm{~g}$ & $50 \mathrm{ml}$ & 0.99674 \\
3 & $26.542 \mathrm{~g}$ & $76.136 \mathrm{~g}$ & $50 \mathrm{ml}$ & 0.99188 \\
4 & $31.7061 \mathrm{~g}$ & $77.5020 \mathrm{~g}$ & $50 \mathrm{ml}$ & 0.91591 \\
\hline 5 & $32.3005 \mathrm{~g}$ & $77.5382 \mathrm{~g}$ & $50 \mathrm{ml}$ & 0.90475 \\
\hline
\end{tabular}

\section{VISCOSITY OF BIODIESEL}

Viscosity test for Biodiesel sample was performed using VR 3000 Viscometer apparatus. However, the viscosity results were varied between 26-37 mpas. The viscosity of biodiesel samples shown in Table 2. 
Table 2: Viscosity of biodiesel samples.

\begin{tabular}{lllll}
\hline $\begin{array}{l}\text { Sampl } \\
\text { eno }\end{array}$ & Type of spindle & $\begin{array}{l}\text { Rotationa } \\
\text { I speed }\end{array}$ & $\begin{array}{l}\text { Temperature } \\
\left({ }^{\circ} \mathrm{C}\right)\end{array}$ & $\begin{array}{l}\text { Viscosity } \\
\text { mpas }\end{array}$ \\
\hline 1 & T-bar & Slow & 24.1 & 37 \\
2 & Disc & Medium & 24.6 & 35 \\
\hline 3 & Cylinder & High & 24.8 & 26 \\
\hline
\end{tabular}

viscosity $1=\frac{37 \times 10}{1000}=0.37$ poise $=370$ milipoise

$$
\begin{aligned}
& \text { viscosity } 2=\frac{35 \times 10}{1000}=0.35 \text { poise }=350 \text { milipoise } \\
& \text { viscosity } 1=\frac{26 \times 10}{1000}=0.26 \text { poise }=260 \text { milipoise } \\
& \text { average }=\frac{0.37+0.35+0.26}{3}=0.326
\end{aligned}
$$

\section{FLASH AND FIRE POINT OF BIODIESEL}

The test of flash and fire point was carried out for purified and un-purified biodiesel sample. The experimental result of flash and fire point for purified sample has been presented in Table 3.

Table 3: Flash and fire point values of biodiesel samples.

\begin{tabular}{lcc}
\hline Temperature & Flash point $\left({ }^{0} \mathrm{C}\right)$ & Fire Point $\left({ }^{0} \mathrm{C}\right)$ \\
Sample No & - & \\
\hline 1 & - & 75 \\
2 & 93 & 120 \\
3 & 112 & 130 \\
\hline 4
\end{tabular}


Sustainability, Agri, Food and Environmental Research, (ISSN: 0719-3726), 10(X), 2022: http://dx.doi.org/

\section{FUNCTIONAL GROUP OF BIODIESEL ESTIMATION}

The functional group of biodiesel methyl ester was estimated with Gas-Chromatography instrument. Thegraph is shown in Fig 2.

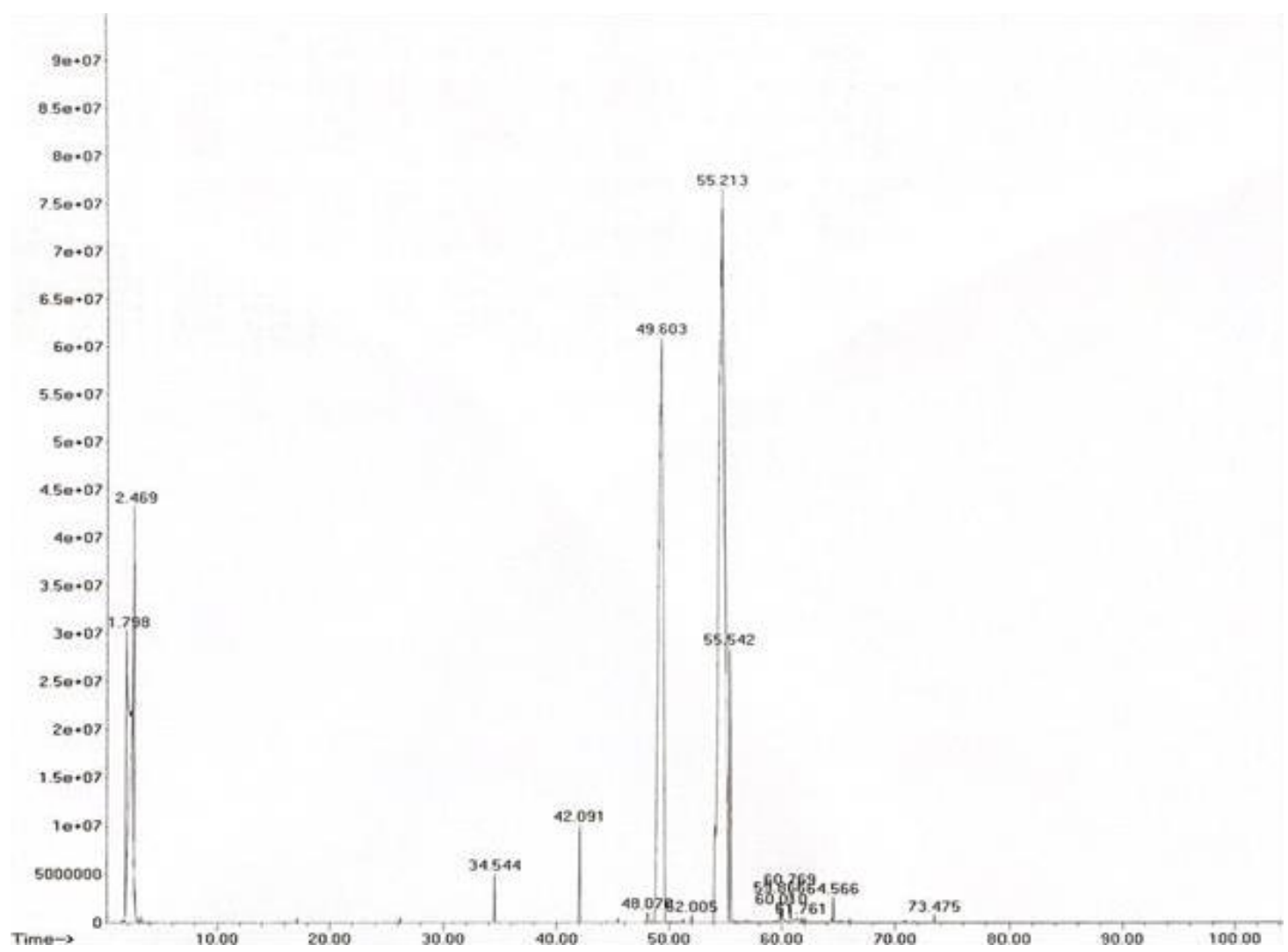

Fig 2: Estimation of methyl ester functional group with Gas Chromatography. 
Sustainability, Agri, Food and Environmental Research, (ISSN: 0719-3726), 10(X), 2022: http://dx.doi.org/

\section{ESTIMATION OF GROSS CALORIFIC VALUE OF BIODIESEL}

Gross Calorific Value (G.C.V) $=\frac{(W-w)(T 2-T 1)^{\circ} \mathrm{C}}{\text { Sample Weight }}$

Where:

$\mathbf{G C V}=$ Gross calorific value of biodiesel in $\mathrm{k} \mathrm{cal} / \mathrm{kg}$

$\mathbf{W}=$ Water weight in gram

$\mathbf{w}=$ std. Standard benzoic acid in gram

$\mathbf{T 1}=$ Initial temperature of water in ${ }^{0} \mathrm{C}$

$\mathbf{T 2}=$ Final temperature of water in ${ }^{\circ} \mathrm{C}$

$\mathbf{T 1}=$ Initial temperature of water in ${ }^{\circ} \mathrm{C}$

$\mathbf{X}=$ Weight of biodiesel sample in gram

The gross calorific value readings are shown in Table 4 below.

Table 4: Gross Calorific Value Readings

\begin{tabular}{lc}
\hline Sample or Bomb ID & A2 \\
\hline Sample Weight g & 0.5000 \\
Spike Weight & 0.0000 \\
Jacket Temperature T2 $\left({ }^{\circ} \mathrm{C}\right)$ & 20.5104 \\
Bucket Temperature T1 $\left({ }^{\circ} \mathrm{C}\right)$ & 19.8810 \\
\hline
\end{tabular}

Temperature Rise $\left({ }^{\circ} \mathrm{C}\right)$ 


$$
\text { Gross Calorific Value }(\text { G.C.V2 })=\frac{(450+2416)(20.5104-19.8810)^{\circ} \mathrm{C}}{0.5000}
$$

$$
\text { G.C.V2 }=3607.7 \mathrm{cal} / \mathrm{gram}
$$

The standards for biodiesel shown in Table 5 below.

Table 5: The Physical and Index Properties of the biodiesel.

\begin{tabular}{ll}
\hline Property & Vale range- Description \\
\hline Color & Pale yellow \\
Odour & Pleasurable \\
Texture & Viscous - freezes in room temperature \\
Density & $0.895-0.998$ \\
Fire point & 198 \\
fatty acid Methyl esters (FAME) & $70 \%-80 \%$ \\
Glycerol & $25 \%-30 \%$ \\
Flammability & Less flammable \\
Produce emotions & Less \\
\hline Maximum Heating value & $9739.3 \mathrm{k} . \mathrm{cal} / \mathrm{kg}$ \\
\hline
\end{tabular}




\section{CONCLUSIONS}

It was observed that the biodiesel produced from date seed oil is closely matches with the prescribed standards of biodiesel. The density of produced biodiesel exactly matches with the specification. The methyl ester functional group in the produced biodiesel was $70 \%$. It matches with the specification.

\section{REFERENCES}

Cerveró, J. M., Coca, J. \& Luque, S., 2008. Production of biodiesel from vegetable oils. Grasas y Aceites. [e- journal]. 59 (1). p. 76-83. Available from: https://www.researchgate.net/publication/26524146

Chhetri, A. B. et al., 2008. Non-Edible Plant Oils as New Sources for Biodiesel Production. International Journal of Molecular Sciences. [e-journal]. 9 (2008). p.169-180. Available from: http://www.mdpi.org/ijms

Gashaw, A. \& Teshita, A., 2014. Production of biodiesel from waste cooking oil and factors affecting its formation: A review. Internationa I Journal of Renewable and SustainableEnergy. [e-journal]. 3 (5). p. 92- 98. Available from: http://www.sciencepublishinggroup.com/j/ijrse

Gibbs, H. K. et al., 2008. Carbon payback times for crop-based biofuel expansion in thetropics: the effects of changing yield and technology. Environmental Research Letters.[e-journal]. 3 (034001). p.1-10. Available from: http:// www.erl.net .

Kurnia, J. C. et al., 2016. Advances in biofuel production from oil palm and palm oil processing wastes: A review. Biofuel Research Journal. [e-journal]. 9 (2016). p. 332-346. Available from: http://www.biofueljournal.net .

Received: $15^{\text {th }}$ February 2021; Accepted: 22 ${ }^{\text {th }}$ April 2021; First distributed: 22 $2^{\text {th }}$ March 2021 